\title{
Correction to: Improvement in Field CBR Values of Subgrade Soil Using Construction-Demolition Materials
}

\section{Moataz A. Al-Obaydi ${ }^{1}$ (D) Mohammed D. Abdulnafaa ${ }^{2}$ (D) Orhan A. Atasoy $^{3}$ • Ali Firat Cabalar ${ }^{4}$}

Published online: 31 May 2021

(C) Springer Science+Business Media, LLC, part of Springer Nature 2021

\section{Author Correction: Transportation Infrastructure Geotechnology https://doi.org/10.1007/s40515-021-00170-x}

The original version of this article unfortunately contained a mistake in the reference list. The reference "Katarzyna, Z.-A., Maria, J.S.: Dynamic CBR test to assess the soil compaction. J. Test. Eval. 43(5), 1028-1036 (2015). https://doi.org/10.1520/ JTE20130256" should be "Zabielska-Adamska, K., Sulewska, M.J.: Dynamic CBR test to assess the soil compaction. J. Test. Eval. 43(5), 1028-1036 (2015). https://doi. org/10.1520/JTE20130256."

The original article has been corrected.

Publisher's Note Springer Nature remains neutral with regard to jurisdictional claims in published maps and institutional affiliations.

The online version of the original article can be found at https://doi.org/10.1007/s40515-021-00170-X

Moataz A. Al-Obaydi

dralobaydi@uomosul.edu.iq

1 Department of Civil Engineering, College of Engineering, University of Mosul, Mosul, Iraq

2 Department of Environmental Engineering, College of Engineering, University of Mosul, Mosul, Iraq

3 Hasan Kalyoncu University, Gaziantep, Turkey

4 Department of Civil Engineering, University of Gaziantep, Gaziantep, Turkey 